\title{
Imigração internacional na macrometrópole paulista: novas e velhas questões
}

International immigration in the São Paulo macrometropolis: new and old questions

Rosana Baeninger [I] Natália Belmonte Demétrio [II] Jóice Domeniconi [III]

\begin{abstract}
Resumo
O objetivo deste trabalho é relacionar as transformações na dinâmica urbana da Macrometrópole Paulista às novas faces de sua imigração internacional. Parte-se da hipótese de que as mudanças na divisão social do trabalho em nível global reconfiguram as formas de organização da metrópole, atribuindo novas funções econômicas a seus municípios, com alteração do perfil de seus imigrantes internacionais. Além de uma discussão teórica sobre reestruturação produtiva, metropolização e migração internacional, o artigo recupera registros administrativos de diferentes órgãos governamentais (Polícia Federal e Comitê Nacional para Refugiados) que reforçam a mudança no perfil da imigração internacional nessa espacialidade. Na análise desses novos fluxos, destacam-se o processo de substituição da população e a produção de novas paisagens étnicas nesses territórios.
\end{abstract}

Palavras-chave: urbanização; metropolização; globalização; migração internacional; dinâmica da população.

\begin{abstract}
The objective of this work is to relate the transformations in the urban dynamics of the São Paulo Macrometropolis to the new faces of its international immigration. Our hypothesis is that changes in the social division of labor at the global level reconfigure the organization forms of the metropolis, attributing new economic functions to its municipalities and changing the profile of their international immigrants. In addition to a theoretical discussion on productive restructuring, metropolization and international migration, the article retrieves administrative records from different government agencies (Federal Police and National Committee for Refugees) that reinforce the change in the profile of international immigration in this area. In the analysis of the new flows, we highlight the process of population replacement and the production of new ethnic landscapes in these territories.
\end{abstract}

Keywords: urbanization; metropolization; globalization; international migration; population dynamics. 


\section{Reestruturação da produção, metropolização e imigração internacional: primeiras considerações}

A despeito das diferentes formas de nomear e entender as transformações em curso nas metrópoles, Lencioni (2003, p. 45) afirma haver relativo consenso entre pesquisadores de que o momento atual marca a "emergência de um novo fato urbano de caráter metropolitano", expresso pela extensão da mancha urbana e reforço à conurbação. A autora relata, ainda, haver uma interpretação comum de que essa nova dinâmica de produção do espaço se associa à chamada reestruturação produtiva: "um momento em que uma nova forma social da produção industrial, materializada nas multinacionais, gesta uma nova metamorfose na forma urbana expressa na metrópole e seus subúrbios" (ibid., p. 47).

De acordo com Harvey (1992), a reestruturação produtiva vem como resposta a uma secular crise de superprodução, subconsumo, desemprego e concentração de capitais que, originada nos países centrais na década de 1970, espalha-se para os países periféricos nos anos 1980 e 1990. Segundo o autor, o endividamento público, somado à crise econômica, levou a uma mudança na forma de operação das empresas, as quais protagonizaram uma intensa

[...] racionalização, reestruturação e intensificação do controle do trabalho [...]. A mudança tecnológica, a automação, a busca de novas linhas de produto e nichos de mercado, a dispersão geográfica para zonas de controle do trabalho mais fácil, as fusões e medidas para acelerar o tempo de giro do capital passaram ao primeiro plano das estratégias corporativas de sobrevivência em condições gerais de deflação. (Ibid., pp. 137 e 140)

A formação das multinacionais resulta, assim, da radicalização dos processos de fusão e aquisição, das taxas altamente intensificadas de inovação comercial, tecnológica e organizacional, da abertura econômica e maior facilidade de trânsito de capitais entre diferentes Estados-Nacionais (ibid.; Sassen, 1998). Para Santos (2013), o desenvolvimento sem precedentes dos meios de comunicação e transporte, conjugado à guerra fiscal como política de alocação de investimento, fomentou o processo de desconcentração da produção, com novas formas de complementaridade socioespacial entre os lugares.

Dentre os processos que mais contribuem para a redefinição da divisão social e territorial do trabalho, o autor destaca uma mais intensa cisão espacial entre gestão e produção, fenômeno responsável por originar tanto localidades especializadas no gerenciamento de investimentos e tomada de decisões, como áreas voltadas quase que exclusivamente à produção de mercadorias, reguladas a distância por formas de comunicação instantâneas (ibid.). Na interpretação do autor, unidos por uma hierarquia qualitativamente distinta, esses espaços do mandar e do fazer conformam uma rede urbana cuja força motriz não está exatamente associada à produção de manufaturas, mas ao controle das atividades hegemônicas ligadas à capacidade de produzir, coletar e classificar informações (ibid.).

Para Sassen (1998), a emergência das multinacionais redefine as desigualdades estruturadas no âmbito da divisão internacional 
do trabalho. Por um lado, sua atuação reitera antigas centralidades, alçando os principais centros de acumulação do mundo à condição de cidades globais especializadas na gestão e coordenação dos investimentos. De acordo com Manrique (2012), esse processo está intimamente associado à desindustrialização em curso nos países centrais, com repercussão direta das taxas de desemprego. Basso (2013) complementa os efeitos da crise econômica na Europa e EUA ao associar as tensões no mundo do trabalho à ascensão do racismo institucional que tanto influencia a adoção de políticas migratórias cada vez mais restritivas.

Por outro lado, a consolidação de novas frentes de crescimento econômico especializadas no processamento de mercadorias para exportação (Sassen, 1998) transformou a China e outros países do sudeste asiático nas principais fábricas do mundo (Manrique, 2012). 0 Brasil, por sua vez, insere-se nos mercados globais como o maior produtor de commodities agrominerais do mundo (Cano, 2011; Brandão, 2007), fenômeno responsável pela dinâmica da reestruturação produtiva e urbana em várias regiões do País (Elias, 2003 e 2017), com expressões marcantes nos processos migratórios internos (Demétrio, 2017) e internacionais (Magalhães, 2017).

Nesse contexto, como se reconfiguram os processos socioespaciais das metrópoles brasileiras? Ao refletir sobre as metamorfoses da metropolização em tempos de reestruturação da produção, Moura (2009) destaca o caráter cada vez mais híbrido e multiescalar desses espaços. De fato, a presença de multinacionais reconfigurou o tecido urbano-metropolitano, fazendo crescer o capital intangível, os investimentos em infraestrutura de transporte e comunicação, a instalação de empresas de consultorias, auditorias, telecomunicações e bancos, alimentando a especulação imobiliária e a expulsão da população de baixa renda das zonas centrais para a periferia (ibid.). No entanto, mesmo em São Paulo, principal centro financeiro do País, a indústria manufatureira tradicional, voltada ao mercado nacional, permanece importante. Tampouco a fluidez do espaço é completa, com dotação tecnológica na conformação do território relativamente precária (ibid.).

Ao analisar a tendência de desconcentração industrial em função da reestruturação produtiva, Lencioni (2003, p. 48) é categórica: "essa dispersão nem é infinita e nem de mesmo conteúdo". Para a autora, embora a revolução dos transportes tenha permitido relativo desenraizamento da indústria, emergiram outras condições de produção que reiteraram a centralidade das metrópoles, tais como a existência de "um mercado altamente qualificado exigido pelo emprego de alta tecnologia", de "um eficaz sistema de circulação viária e de aeroportos internacionais", de centros de tecnologia de ponta e de "expressivo mercado consumidor" (ibid., p. 51). Por essa razão, mesmo diante de "toda infraestrutura de fibra ótica e das infinitas possibilidades da informática", "os serviços de consultoria, assessoria, auditoria, bolsas, seguradoras" localizados no núcleo metropolitano (ibid.) continuam a criar economias de aglomeração, ampliando sua área influência (Faria, 1981).

É no escopo dessas transformações que se deve analisar a formação de um complexo metropolitano ampliado, que se estende em um raio não superior a $200 \mathrm{~km}$ da capital, articulando 174 municípios em 5 regiões metropolitanas (São Paulo, Campinas, Sorocaba, Baixada Santista e Vale do Paraíba e Litoral Norte) 
e duas aglomerações urbanas (Piracicaba e Jundiaí) e uma microrregião (Bragantina) (Emplasa/Seade, 2011 e Emplasa, 2012). Segundo Lencioni (2003), a reestruturação produtiva atingiu fortemente essa região, atribuindo novas funções econômicas aos seus municípios, principalmente à cidade de São Paulo, que, de centro fabril dos anos 1920 , passa a se destacar pelas finanças e pelos serviços especializados no século XXI.

Negri, Gonçalves e Cano (1988) sublinham, contudo, a anterioridade da desconcentração da produção industrial paulista em relação à reestruturação produtiva. Esse fenômeno inicia-se ainda nos anos 1970, nos marcos dos planos nacionais de desenvolvimento, antes mesmo da abertura econômica e dos privilégios concedidos às multinacionais no País (Cano, 2011). Na década de 1980, essa tendência de interiorização da indústria é reforçada, mas com motivações e consequências completamente distintas (ibid.). Sob os efeitos da crise econômica e da guerra fiscal, muitas fábricas saem da capital e da região do $A B C$, rumo a Mogi das Cruzes, Guarulhos, Franco da Rocha, espraiando-se, ainda, pela região de Campinas, São José dos Campos e Santos: espacialidades que, desde o século passado, já haviam desenvolvido suas atividades urbanas no seio do complexo cafeeiro (Negri, Gonçalves, Cano, 1988). Por essa razão, Lencioni (2003, p. 53) destaca: "a reestruturação produtiva, como constituição de uma nova lógica histórica de produção do capital, ao alterar as determinações das estratégias e práticas territoriais da indústria, o fez reafirmando a tradicional área industrial do interior".

Ao tomar como unidade de análise esse complexo metropolitano ampliado, Campolina Diniz e Campolina (2007) recolocam a hipótese de desindustrialização associada à mudança no padrão locacional da indústria. Nas palavras dos autores: "embora possa estar havendo uma desindustrialização no país, pela queda do peso da indústria no produto e no emprego total, pela expansão das exportações de 'commodities' agrícolas e minerais e de produtos semielaborados, o fenômeno na RMSP precisa ser avaliado desde outra perspectiva" (p. 53). Na visão dos autores, os 533 mil postos de trabalho formais perdidos na indústria, na RMSP, entre 1985-2005, foram mais que "compensados pelo ganho de 1.388 mil nos setores de comércio, serviços e outros" (ibid., p. 50). Ademais, na década de 1990, a queda da produção industrial da RMSP foi relativamente pequena, indicando ganhos em produtividade em um contexto mais amplo de "estagnação, reestruturação e não desindustrialização" (ibid., p. 34).

A reestruturação da produção significou, portanto, uma reconversão econômica da Região Metropolitana de São Paulo, sobretudo de sua capital, por meio da qual se ampliam suas "funções de direção, especialmente financeira e de mercados de capitais, das atividades intensivas em conhecimento e inovação, além de seu papel como centro de consumo" (ibid., p. 31). No entanto, é fundamental destacar a permanência de outros setores que, embora não inseridos nos mercados globais, permanecem primordiais na dinamização da metrópole (Moura, 2009).

Para Magalhães e Bógus (2018, p. 1), essa reconversão econômica, "mais que deslocar a força de trabalho entre os diferentes setores da economia, irá alterar a composição do mercado de trabalho, expulsando trabalhadores de um perfil e absorvendo trabalhadores de outros perfis". Junto à mudança na composição 
da força de trabalho, Baeninger (2012) destaca maior complexidade nos processos de redistribuição espacial dessa população. Na interpretação da autora, a inovação tecnológica e as facilidades de transporte, conjugadas ao quadro da reestruturação produtiva, levaram a uma situação de precarização das relações de trabalho responsável por desencadear uma nova configuração dos processos migratórios: a rotatividade. Nesse sentido, quanto mais intensa for a reestruturação da produção, mais rotativa tende a ser a dinâmica da população, com surgimento de variadas modalidades migratórias não previstas pelos aportes teóricos clássicos.

Dentre os diversos desafios que esse cenário impõe aos estudos migratórios, Baeninger (2005, p. 90) sublinha o fim do "paradigma explicativo da emigração como um dos efeitos sociais negativos do menor crescimento econômico e, sobretudo, da ausência de atividades industriais fortes". Ao criar um mercado de trabalho competitivo e instável, os espaços de inserção privilegiada na divisão socioespacial do trabalho retêm somente a menor parte dos migrantes: os qualificados. Por essa razão, as zonas luminosas (Santos, 2013) consolidam-se como áreas de rotatividade ou mesmo de expulsão para a grande maioria da população, enquanto as áreas mais opacas em termos da presença de capital internacional podem se destacar pelo ritmo mais acelerado de crescimento populacional (Baeninger, 2005).

No tocante à dinâmica das migrações internacionais, a inserção privilegiada do País na atual divisão internacional do trabalho marca a sua consolidação na rota das migrações transnacionais, tanto de mão de obra qualificada, como de menor qualificação (Baeninger,
2014). Nesse contexto, a Macrometrópole Paulista - e sobretudo a cidade de São Paulo destaca-se como o principal ponto de chegada, saída e trânsito de migrantes internacionais, seja pela presença das multinacionais, seja pela demanda de trabalho qualificado, seja pela ampla oferta de empregos "de baixa qualificação, da existência de redes migratórias já consolidadas e de maior estrutura de acolhimento e acompanhamento a imigrantes e refugiados" (Magalhães; Bógus, 2018, p. 2). Se, entre as ocupações associadas à inovação tecnológica, sobressaem os fluxos provenientes do Norte Global - embora não somente (Domeniconi, 2018) -, nas ocupações referentes à globalização por baixo (Portes; Guarnizo, Landolt, 2003) são as migrações Sul-Sul as grandes protagonistas (Magalhães; Bógus, Baeninger, 2018).

Desse modo, os espaços históricos da imigração de massa de fins do século XIX e início do XX, composta majoritariamente por espanhóis, italianos e portugueses, são redefinidos com a chegada de bolivianos, peruanos e paraguaios na segunda metade do século passado, reconfigurando-se novamente com o recente fluxo de haitianos, senegaleses, ganeses, angolanos ou sírios (ibid.). Apesar da evidente concentração desses imigrantes nas regiões centrais, Magalhães, Bógus e Baenigner (ibid.) destacam como a lógica de produção da cidade os empurram para localidades cada vez mais periféricas. Na capital, o "fio condutor" que canaliza a distribuição desses imigrantes Sul-Sul se origina nos distritos da Sé, do Brás, do Pari e do Bom Retiro, alcançando a Zona Leste (ibid., 2018, p. 405). Em Campinas, esse cordão inicia-se na região central e no distrito de Barão Geraldo, com os novos imigrantes internacionais espalhando-se na porção sudoeste do município, rumo à Hortolândia e Sumaré, 
principalmente (Baeninger; Custódio, 2018). Até mesmo localidades mais distantes do centro metropolitano, como Americana, registram aumento do fluxo de imigrantes internacionais associado à reestruturação urbana e de suas atividades econômicas (Oliveira, 2017).

À luz dessas transformações, este artigo tem como objetivo analisar a inserção dos municípios da Macrometrópole Paulista na dinâmica das migrações internacionais contemporâneas. Em outros termos, busca-se refletir sobre como as estruturas socioeconômicas que inserem esses municípios na divisão internacional do trabalho têm atraído, absorvido, expulsado e redistribuído imigrantes internacionais, de diversas nacionalidades, perfis e formas de inserção laboral.

\section{O uso de registros administrativos nos estudos sobre migração internacional}

A intensidade das mudanças, dos sentidos, das origens e das modalidades migratórias requer a articulação de diferentes fontes de informação e metodologias de pesquisa (Baeninger, Fernandes, 2017 e 2018; Oliveira, Cavalcante, 2015; Magalhães, Bógus, 2018). Tendo em vista o principal objetivo deste trabalho - elaborar um panorama da imigração internacional na Macrometrópole Paulista nas primeiras décadas do século XXI -, o primeiro desafio a enfrentar diz respeito às fontes de informação quantitativas. Pelo fato da consolidação do Brasil na rota das migrações transnacionais ocorrer depois da realização do último Censo Demográfico, em 2010, grande parte da nova migração internacional para o Brasil não foi captada por esse levantamento (Baeninger, 2017a). Tampouco a periodicidade dessa pesquisa possibilita o acompanhamento das reconfigurações do fenômeno no intervalo intercensitário (Baeninger; Fernandes, 2017).

De modo a contornar essas questões, os registros administrativos têm sido amplamente utilizados, apesar dos problemas de coleta e acesso a essas fontes (Baeninger e Fernandes, 2017; Oliveira, Cavalcante, 2015). Este trabaIho combina dois registros principais, os quais permitem a construção geral das mudanças e reconfigurações da dinâmica imigratória para a Macrometrópole Paulista. 0 primeiro deles refere-se ao Sistema Nacional de Cadastros e Registros (Sincre): registro administrativo da Polícia Federal, por meio do qual se faz o controle de todos os estrangeiros com carteira de identidade.

A lacuna com relação à situação dos solicitantes de refúgio - pessoas não incluídas nessa base e cujo fluxo tem aumento significativamente nos últimos anos - conduz a exploração de outro registro: o do Comitê Nacional para Refugiados (Conare), vinculado ao Ministério da Justiça. Ainda que em caráter provisório, aos solicitantes de refúgio, é garantido o direito de acesso ao Cadastro de Pessoa Física (CPF) e Carteira de Trabalho e Previdência Social (CPTS), com possibilidade de inserção no mercado de trabalho formal.

Mesmo que de modo parcial, sem cobrir os indocumentados ${ }^{1}$ - importante na inserção laboral da migração Sul-Sul (Magalhães; Bógus, Baeninger, 2018) -, a combinação dessas fontes de informação permite iluminar a emergência de novos fluxos, as dinâmicas diferenciadas de inserção laboral, amparo legal, distribuição espacial e estrutura etária para diferentes países. ${ }^{2}$ 


\section{Tendências e características das migrações internacionais na Macrometrópole Paulista: uma análise com base nos registros administrativos da Política Federal}

No Brasil, cabe à Polícia Federal - alocada no Ministério da Justiça e Segurança Pública - o registro dos imigrantes internacionais residentes no País. Esse controle ocorre por meio do Sistema Nacional de Cadastro e Registro de Estrangeiro (Sincre), fonte de informação de todos os imigrantes internacionais com Registro Nacional de Estrangeiro (RNE). ${ }^{3}$ Por permitir desagregação em nível municipal, identificação dos amparos legais que garantem a residência no Brasil, além de outras informações como tipo de visto, idade, sexo e ocupação, essa fonte tem sido amplamente explorada pelo Observatório das Migrações em São Paulo e por outros grupos de pesquisa. Vale destacar, no entanto, que, diferentemente do censo demográfico, essa fonte de informação não é capaz de estimar o total de imigrantes internacionais residentes no País. Uma vez emitido o RNE, a pessoa permanece na base do Sincre mesmo tendo deixado o País tempos depois. A essa limitação, somam-se os problemas de preenchimento, publicidade e acesso, ${ }^{4}$ a não consideração dos indocumentados e dos solicitantes de refúgio.

Em linhas gerais, entre 2000 e 2017, foram emitidos mais de um milhão de RNEs no Brasil (Gráfico 1), 460 mil dos quais referentes

Gráfico 1 - Imigrantes internacionais registrados (Registro Nacional de Estrangeiro - RNE), segundo ano do registro. Brasil e Macrometrópole Paulista, 2000 a 2017

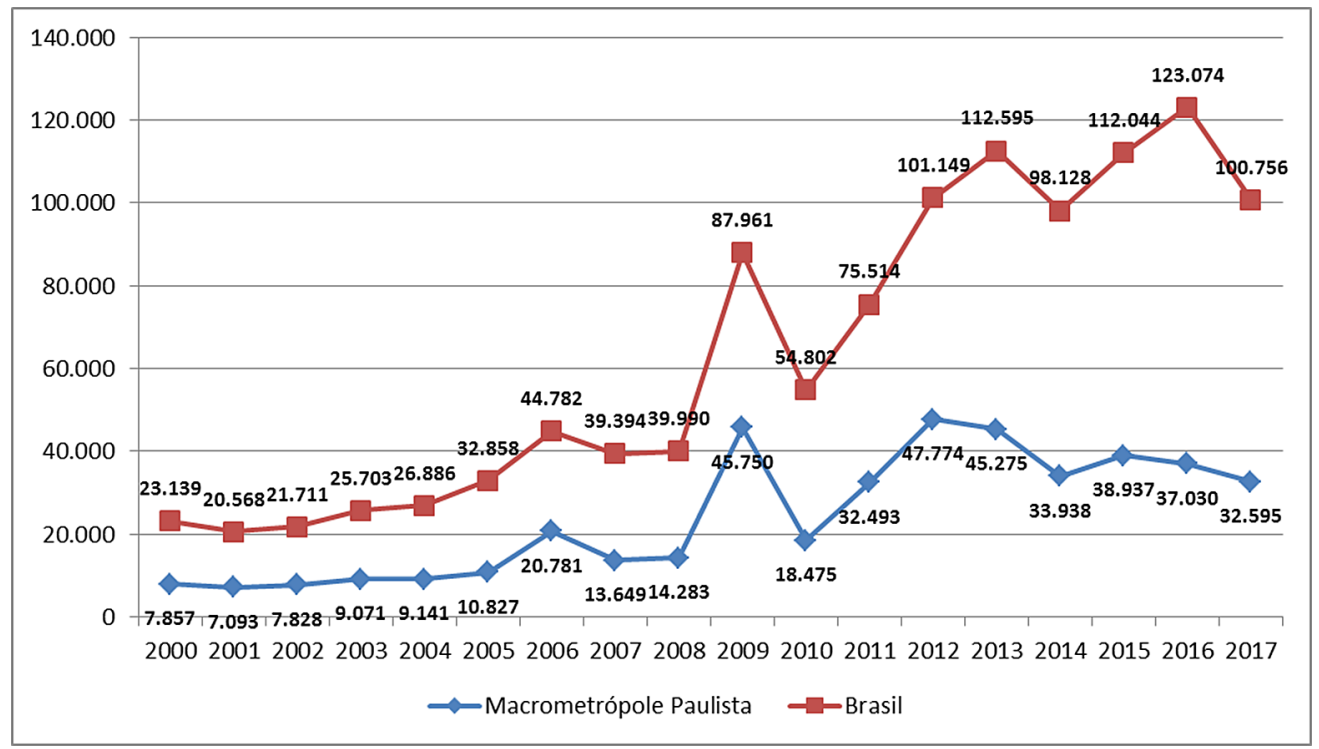

Fonte: Sistema Nacional de Cadastros e Registros (Sincre), Departamento da Polícia Federal - Ministério da Justiça e Segurança Pública do Brasil/OBMigra.

Tabulações: Observatório das Migrações em São Paulo - Nepo/Unicamp-CNPq. 
Tabela 1 - Imigrantes internacionais registrados (Registro Nacional de Estrangeiro - RNE) segundo ano do registro e taxa geométrica de crescimento dos registros (em \% a.a.).

Macrometrópole Paulista, restante do Estado de São Paulo e o conjunto do território estadual, 2000 a 2017

\begin{tabular}{|c|c|c|c|c|c|c|}
\hline \multirow[t]{2}{*}{ Ano } & \multicolumn{2}{|c|}{ Macrometrópole paulista } & \multicolumn{2}{|c|}{$\begin{array}{l}\text { Restante do Estado } \\
\text { de São Paulo }\end{array}$} & \multicolumn{2}{|c|}{ Estado de São Paulo } \\
\hline & Registros & $\%$ & Registros & $\%$ & Registros & $\%$ \\
\hline 2000 & 7.857 & 92,4 & 642 & 7,6 & 8.499 & 100,0 \\
\hline 2001 & 7.093 & 92,8 & 548 & 7,2 & 7.641 & 100,0 \\
\hline 2002 & 7.828 & 92,7 & 613 & 7,3 & 8.441 & 100,0 \\
\hline 2003 & 9.071 & 93,3 & 563 & 6,7 & 9.724 & 100,0 \\
\hline 2004 & 9.141 & 92,4 & 756 & 7,6 & 9.897 & 100,0 \\
\hline 2005 & 10.827 & 91,8 & 968 & 8,2 & 11.795 & 100,0 \\
\hline 2006 & 20.781 & 95,7 & 934 & 4,3 & 21.715 & 100,0 \\
\hline 2007 & 13.649 & 94,3 & 819 & 5,7 & 14.468 & 100,0 \\
\hline 2008 & 14.283 & 94,6 & 823 & 5,4 & 15.106 & 100,0 \\
\hline 2009 & 45.750 & 96,5 & 1.647 & 3,5 & 47.397 & 100,0 \\
\hline 2010 & 18.475 & 92,8 & 1.431 & 7,2 & 19.906 & 100,0 \\
\hline 2011 & 32.493 & 94,6 & 1.844 & 5,4 & 34.337 & 100,0 \\
\hline 2012 & 47.774 & 95,3 & 2.352 & 4,7 & 50.126 & 100,0 \\
\hline 2013 & 45.275 & 94,3 & 2.742 & 5,7 & 48.017 & 100,0 \\
\hline 2014 & 33.938 & 92,9 & 2.577 & 7,1 & 36.515 & 100,0 \\
\hline 2015 & 38.937 & 92,5 & 3.156 & 7,5 & 42.093 & 100,0 \\
\hline 2016 & 37.030 & 91,5 & 3.451 & 8,5 & 40.481 & 100,0 \\
\hline 2017 & 32.595 & 91,3 & 3.093 & 8,7 & 35.688 & 100,0 \\
\hline Total & 432.797 & 93,7 & 29.049 & 6,3 & 461.846 & 100,0 \\
\hline $\begin{array}{l}\text { Taxa geométrica de } \\
\text { crescimento dos registros entre } \\
2000 \text { e } 2017 \text { (em \% a.a.) }\end{array}$ & \multicolumn{2}{|c|}{8,7} & \multicolumn{2}{|c|}{9,7} & \multicolumn{2}{|c|}{8,8} \\
\hline
\end{tabular}

Fonte: Sistema Nacional de Cadastros e Registros (Sincre), Departamento da Polícia Federal - Ministério da Justiça e Segurança Pública do Brasil/OBMigra. Tabulações Observatório das Migrações em São Paulo - Nepo/Unicamp-CNPq

a pessoas que declararam residir no estado de São Paulo, com a Macrometrópole Paulista concentrando mais de $90 \%$ desses registros (Tabela 1). A despeito de São Paulo ainda concentrar a maior parte de imigrantes internacionais residente no Brasil, o Gráfico 1 aponta indícios que reforçam uma outra tendência. Sobretudo a partir de 2014, cada vez mais as emissões desse documento em território paulista não acompanham a tendência verificada para o resto do Brasil. Essa evidência aponta para a reconfiguração espacial da migração internacional em território brasileiro, com emergência de outros espaços da migração internacional no País, a exemplo do oeste catarinense (Magalhães, 2017) e dos estados da fronteira norte (Baeninger; Canales, 2018). Nesse contexto, o aumento das emissões de 
RNE em 2016, para Brasil, não se verifica para São Paulo, cujos volumes são declinantes desde 2015 (Gráfico 1).

Em nível intraestadual, o fortalecimento de espaços da migração internacional no interior também se verifica (Tabela 1). Enquanto os registros da Macrometrópole cresceram $8,7 \%$ a.a. entre 2000 e 2017; para o restante do estado, essa taxa é de $9,7 \%$ a.a. Ainda assim, as emissões de RNEs nos municípios da Macrometrópole concentram mais de $90 \%$ desses registros, reiterando a centralidade dessa espacialidade como área fundamental na entrada e redistribuição dessa população no cenário estadual e, até mesmo, nacional (Gráfico 1; Tabela 1).

O conjunto de informações sistematizadas no Gráfico 1 e Tabela 1 também reforça o pico de emissões de RNE em 2009, tanto no Brasil, como no estado de São Paulo e, em especial, na Macrometrópole Paulista. Segundo Fernandes et al. (2014), esse aumento deve-se à lei de anistia (lei 11.961, de 2 de julho de 2009), que permitiu a regularização de quase 30 mil pessoas em situação indocumentada apenas na Macrometrópole (Tabela 2).

Antes de passar à análise dos principais amparos legais que garantem a residência do imigrante no País, é fundamental destacar ainda com base no Gráfico 1 e Tabela 1 - a recente diminuição das emissões de RNE na Macrometrópole Paulista. Esse fato, não observado no mesmo ritmo para o restante do estado e do País, não necessariamente reflete arrefecimento da imigração internacional nessa espacialidade. Ao contrário, pode espelhar a importância crescente de solicitantes de refúgio, os quais, embora documentados, não possuem RNE e, portanto, não estão registrados no Sincre.
De fato, o amparo legal referente à lei n. 9.474 (Estatuto do Refugiado) desponta-se entre os dispositivos jurídicos mais recorrentes na garantia do direito à residência dos imigrantes na Macrometrópole Paulista, respondendo a $0,7 \%$ (3.009) do total de RNEs emitidos no período considerado (Tabela 2). Além dessa legislação, a Tabela 2 reforça a importância central do acordo de residência dos países-membros e associados do Mercado Comum do Sul (Mercosul) - à luz do qual foi garantido o direito à residência para mais de 100 mil pessoas (quase $24 \%$ de todos os registros) -, dos marcos jurídicos referentes a cientistas, professores e técnicos (tanto o artigo 14 inciso $\mathrm{V}$ do Estatuto do Estrangeiro, quanto à resolução normativa 27, de dezembro de 2009, do Conselho Nacional de Imigração), reunificação familiar, estudantes, missionários religiosos e outros casos não previstos na Lei de Migração vigente até fins de 2017 (Tabela 2).

Nesse contexto, além da própria Região Metropolitana de São Paulo, emergem novos espaços da migração internacional. Os eixos das rodovias Dutra (que liga a capital ao Vale do Paraíba, passando por São José dos Campos) e, sobretudo, Anhanguera/Bandeirantes, entre São Paulo e Campinas, sobressaem como os principais veios de expansão da migração internacional na Macrometrópole (Mapa 2). A partir de Campinas, fortalecem-se tanto a ramificação para Sorocaba, como para Piracicaba, atravessando Sumaré, Americana e Limeira (Mapas 1 e 2).

As diferentes especializações produtivas que estruturam cada sub-região da Macrometrópole podem ser analisadas tendo como proxy a ocupação presente no registro desses imigrantes (Tabela 3). Vale ponderar, no entanto, a não adequação dessa variável 
Tabela 2 - Imigrantes internacionais registrados (Registro Nacional de Estrangeiro - RNE) entre 2000 e 2017, residentes na Macrometrópole Paulista, segundo principais amparos legais

\begin{tabular}{|c|c|c|c|}
\hline Amparo Legal & Descrição Amparo Legal & Total & $\%$ \\
\hline \multicolumn{2}{|c|}{ Acordo de residência do Mercosul } & 103.567 & 23,9 \\
\hline $\begin{array}{l}\text { Artigo } 13, \mathrm{~V} \text {, Lei } \\
6.815 / 1980 \text { (Estatuto } \\
\text { do Estrangeiro) }\end{array}$ & $\begin{array}{l}\text { Define a concessão de visto temporário para estrangeiros na condição } \\
\text { de cientista, professor, técnico ou profissional de outra categoria, sob } \\
\text { regime de contrato ou a serviço do Governo brasileiro }\end{array}$ & 81.485 & 18,8 \\
\hline $\begin{array}{l}\text { Artigo } 75, \text { II, Lei } \\
6.815 / 1980 \text { (Estatuto } \\
\text { do Estrangeiro) }\end{array}$ & $\begin{array}{l}\text { Define os casos em que não pode haver expulsão da pessoa, segundo } \\
\text { o Estatuto do Estrangeiro (casamento ou por ter filho brasileiro) }\end{array}$ & 35.557 & 8,2 \\
\hline Lei 11.961 de 2009 & $\begin{array}{l}\text { Dispõe sobre a residência provisória para o estrangeiro em situação } \\
\text { irregular no território nacional e dá outras providências. }\end{array}$ & 29.387 & 6,8 \\
\hline $\begin{array}{l}\text { Artigo 13, inciso IV, Lei } \\
6.815 / 1980 \text { (Estatuto } \\
\text { do Estrangeiro) }\end{array}$ & $\begin{array}{l}\text { Disciplina a concessão de visto temporário ao estrangeiro que } \\
\text { pretenda vir ao Brasil na condição de estudante }\end{array}$ & 27.602 & 6,4 \\
\hline $\begin{array}{l}\text { Resolução Normativa } \\
36 \text { de } 1999 \text { do CNIg }\end{array}$ & $\begin{array}{l}\text { Disciplina a concessão de visto temporário ou permanente a título de } \\
\text { reunião familiar }\end{array}$ & 26.573 & 6,1 \\
\hline $\begin{array}{l}\text { Artigo } 1 \text { da Resolução } \\
\text { Normativa } 108 \text { de } 2014 \\
\text { do CNIg }\end{array}$ & $\begin{array}{l}\text { Dispõe sobre a concessão de visto temporário ou permanente e } \\
\text { permanência definitiva a título de reunião familiar }\end{array}$ & 22.094 & 5,1 \\
\hline $\begin{array}{l}\text { Artigo } 13, \mathrm{l} \text {, Lei } \\
6.815 / 1980\end{array}$ & $\begin{array}{l}\text { Disciplina a concessão de visto temporário ao estrangeiro que } \\
\text { pretenda vir ao Brasil em viagem cultural ou em missão de estudos }\end{array}$ & 19.862 & 4,6 \\
\hline $\begin{array}{l}\text { Artigo } 16 \text { da Lei } \\
6.815 / 1980 \text { (Estatuto } \\
\text { do Estrangeiro) }\end{array}$ & $\begin{array}{l}\text { Disciplina a concessão de visto permanente nos casos em que a } \\
\text { imigração propicie, primordialmente, mão-de-obra especializada aos } \\
\text { vários setores da economia nacional, visando à Política Nacional de } \\
\text { Desenvolvimento em todos os aspectos e, em especial, ao aumento da } \\
\text { produtividade, à assimilação de tecnologia e à captação de recursos } \\
\text { para setores específicos }\end{array}$ & 18.743 & 4,3 \\
\hline \multicolumn{2}{|l|}{ Dependente de titular } & 11.276 & 2,6 \\
\hline $\begin{array}{l}\text { Resolução normativa } \\
\text { no27, de 25/11/1998, } \\
\text { do CNIg }\end{array}$ & Disciplina a avaliação de situações especiais e casos omissos. & 8.219 & 1,9 \\
\hline $\begin{array}{l}\text { Resolução Normativa } \\
62 \text { de } 8 / 12 / 2004 \text {, do } \\
\text { CNIg }\end{array}$ & $\begin{array}{l}\text { Disciplina a concessão de autorização de trabalho e de visto } \\
\text { permanente a estrangeiro administrador, gerente, diretor ou } \\
\text { executivo, com poderes de gestão, de Sociedade Civil ou Comercial, } \\
\text { Grupo ou Conglomerado econômico }\end{array}$ & 7.114 & 1,6 \\
\hline $\begin{array}{l}\text { Artigo } 37 \text { da Lei } \\
6.815 / 1980 \text { (Estatuto } \\
\text { do Estrangeiro) }\end{array}$ & Disciplina sobre a transformação de vistos & 6.211 & 1,4 \\
\hline $\begin{array}{l}\text { Resolução Normativa } \\
39 \text { de } 1999\end{array}$ & $\begin{array}{l}\text { Dispõe sobre a concessão de visto para ministros de confissão religiosa } \\
\text { ou membro de instituição da vida consagrada ou confessional, e de } \\
\text { congregação ou ordem religiosa que venha ao País para prestação de } \\
\text { serviços de assistência religiosa ou na condição de estudante }\end{array}$ & 5.853 & 1,4 \\
\hline $\begin{array}{l}\text { Portaria } 526 / 1995 \text { do } \\
\text { Ministério da Justiça }\end{array}$ & $\begin{array}{l}\text { Institui modelo único de Cédula de Identidade para Estrangeiro, } \\
\text { determina o recadastramento dos estrangeiros residentes no País e dá } \\
\text { outras providências }\end{array}$ & 3.140 & 0,7 \\
\hline $\begin{array}{l}\text { Lei } 9.474 \text { de } 1997 \\
\text { (Estatuto do Refugiado) }\end{array}$ & $\begin{array}{l}\text { Define mecanismos para a implementação do Estatuto dos Refugiados } \\
\text { de } 1951 \text {, e determina outras providências }\end{array}$ & 3.009 & 0,7 \\
\hline $\begin{array}{l}\text { Amparos legais } \\
\text { considerados }\end{array}$ & & 409.692 & 94,7 \\
\hline $\begin{array}{l}\text { Todos os amparos } \\
\text { legais }\end{array}$ & & 432.797 & 100,0 \\
\hline
\end{tabular}

Fonte: Sistema Nacional de Cadastros e Registros (Sincre), Departamento da Polícia Federal - Ministério da Justiça e Segurança Pública do Brasil/OBMigra. Tabulações Observatório das Migrações em São Paulo - Nepo/Unicamp-CNPq. 
com padronizações reconhecidas internacionalmente. Por essa razão, profissões como "decorador" e "arquiteto" podem representar problemas de coleta da informação e não representar atividade tal como apresentada na Classificação Brasileira de Ocupação. ${ }^{5}$
A despeito dessa inconsistência, é possível apreender a RMSP como espacialidade que concentra tanto a migração qualificada (haja vista reunir $82,6 \%$ dos registros de imigrantes diretores, gerentes e proprietários, $87 \%$ dos médicos, $80 \%$ dos programadores,

Mapa 1 - Imigrantes internacionais registrados (Registro Nacional de Estrangeiro - RNE), segundo ano do registro e município de residência. Macrometrópole Paulista, 2000, 2005, 2010, 2015 e 2017
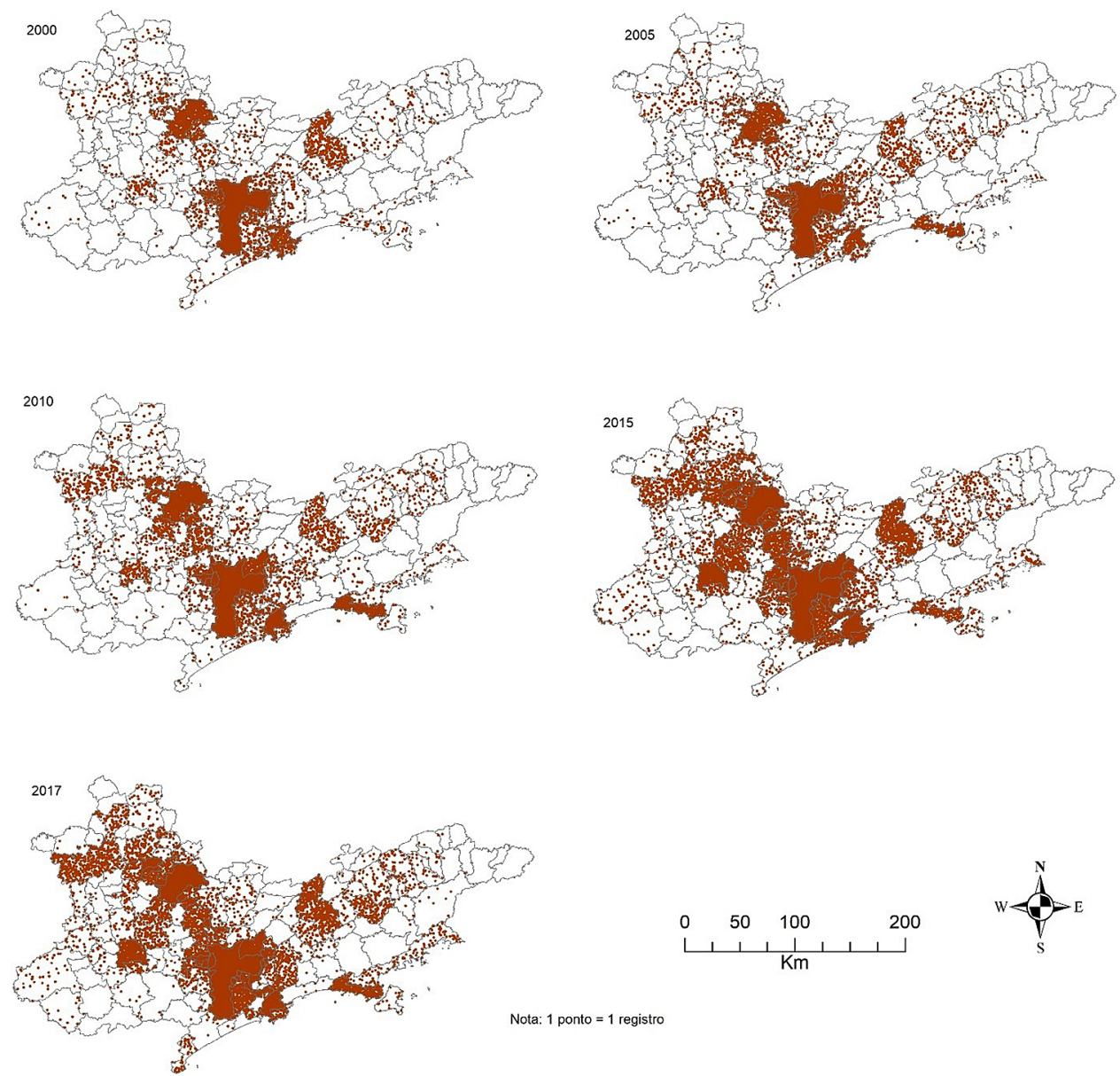

Nota: 1 ponto $=1$ registro

Fonte: Sistema Nacional de Cadastros e Registros (Sincre), Departamento da Polícia Federal - Ministério da Justiça e Segurança Pública do Brasil/OBMigra.

Tabulações: Observatório das Migrações em São Paulo - Nepo/Unicamp-CNPq. 
Mapa 2 - Imigrantes internacionais registrados (Registro Nacional de Estrangeiro - RNE), entre 2000 e 2017, residentes na Macrometrópole Paulista

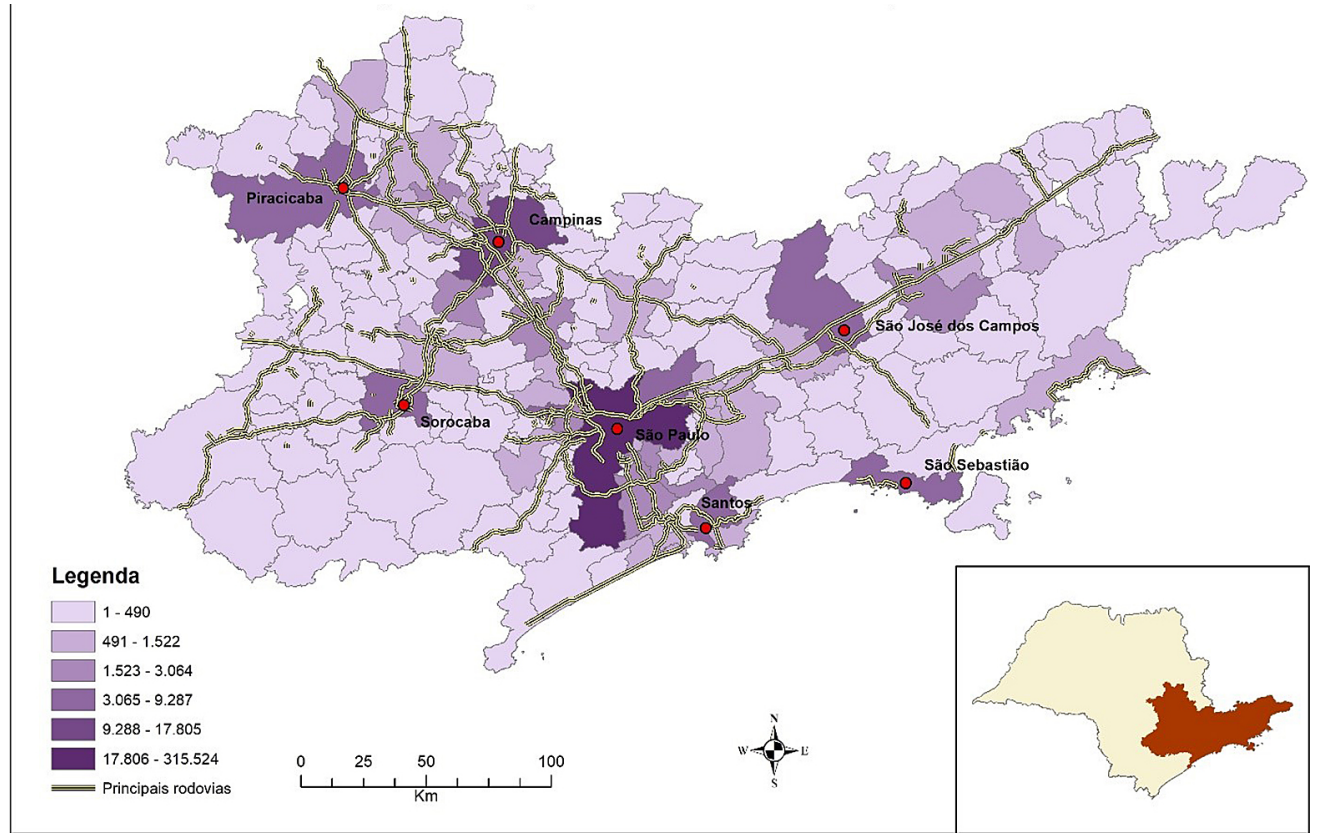

Fonte: Sistema Nacional de Cadastros e Registros (Sincre), Departamento da Polícia Federal - Ministério da Justiça e Segurança Pública do Brasil/OBMigra.

Tabulações: Observatório das Migrações em São Paulo - Nepo/Unicamp-CNPq.

$85 \%$ dos economistas e $87 \%$ dos administradores ou funcionários executivos), como a migração de menor qualificação (a exemplo dos decoradores, os quais têm mais de $98 \%$ de seus registros na RMSP, porteiros ou pessoas sem ocupação) (Tabela 3). A Região Metropolitana da Baixada Santista, por sua vez, desponta-se pela presença de oficiais e aposentados, com $13,7 \%$ e $20 \%$ dos registros referentes a tais ocupações.

Já Região Metropolitana de Campinas emerge como importante polo tecnológico, de pesquisa e de ensino, na medida em que concentra $11,8 \%$ dos registros de estudantes, $12,6 \%$ de professores, $12,5 \%$ de engenheiros e $20 \%$ de bolsistas (Tabela 3). 0 Vale do Paraíba e Litoral Norte despontam-se pela participação dos oficiais (mais de 4.500 registros ou $12,3 \%$ ), arquitetos (1.111 ou $12,5 \%$ ), engenheiros $(12,1 \%$ ou 652$)$ e mecânicos $(15,4 \%$ ou 125 registros). Engenheiros também se sobressaem na Região Metropolitana de Sorocaba e na Aglomeração Urbana de Piracicaba, eletricistas na Aglomeração Urbana de Jundiaí e aposentados na Unidade Regional Bragantina (Tabela 3). 


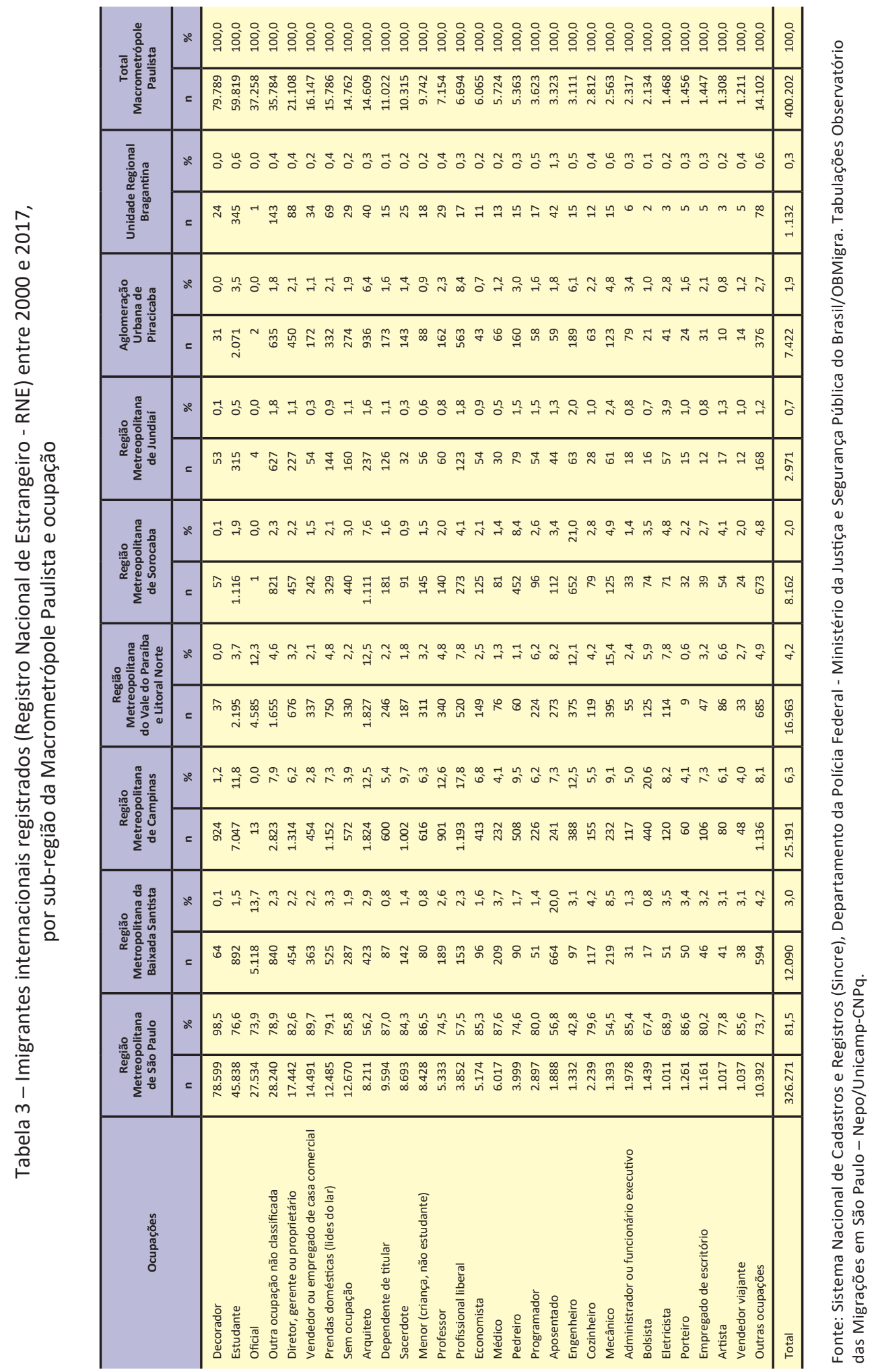


Com relação ao país de nascimento, africanos (em especial nigerianos) e latino-americanos (sobretudo bolivianos) estão mais concentrados na RMSP (Tabela 4). Filipinos sobressaem-se em Santos. Norte-americanos, colombianos, japoneses e alemães estão entre os principais fluxos da região de Campinas. No Vale do Paraíba, despontam-se filipinos e argentinos. Japoneses estão também na Região Metropolitana de Santos e na AU de Jundiaí, enquanto Piracicaba emerge como um importante espaço da migração coreana (Tabela 4). Registros de haitianos, importantes em quase todas as sub-regiões da Macrometrópole Paulista, são inexpressivos nas regiões de Santos, no Vale do Paraíba e Unidade Regional Bragantina. Chineses, outro grande fluxo presente no Sincre, concentram-se na RMSP e na RMVPLN (Tabela 4).

O Gráfico 2 reforça a importância crescente dos países do Sul Global na composição dos registros do Sincre (Baeninger, 2017a). Os latino-americanos e caribenhos mais que duplicaram sua participação entre 2000 e 2017, passando de $25 \%$ para $53,3 \%$. Os registros de europeus, ao contrário, passaram de quase 30\%, em 2000, para menos de 14\% em 2017. Com tendência semelhante, norte-americanos diminuíram de $14,3 \%$ para 3,5\% nesse período (Gráfico 2).

Gráfico 2 - Proporção de imigrantes internacionais registrados (Registro Nacional de Estrangeiro - RNE), segundo ano do registro e regiões do mundo de nascimento Macrometrópole Paulista, 2000 a 2017

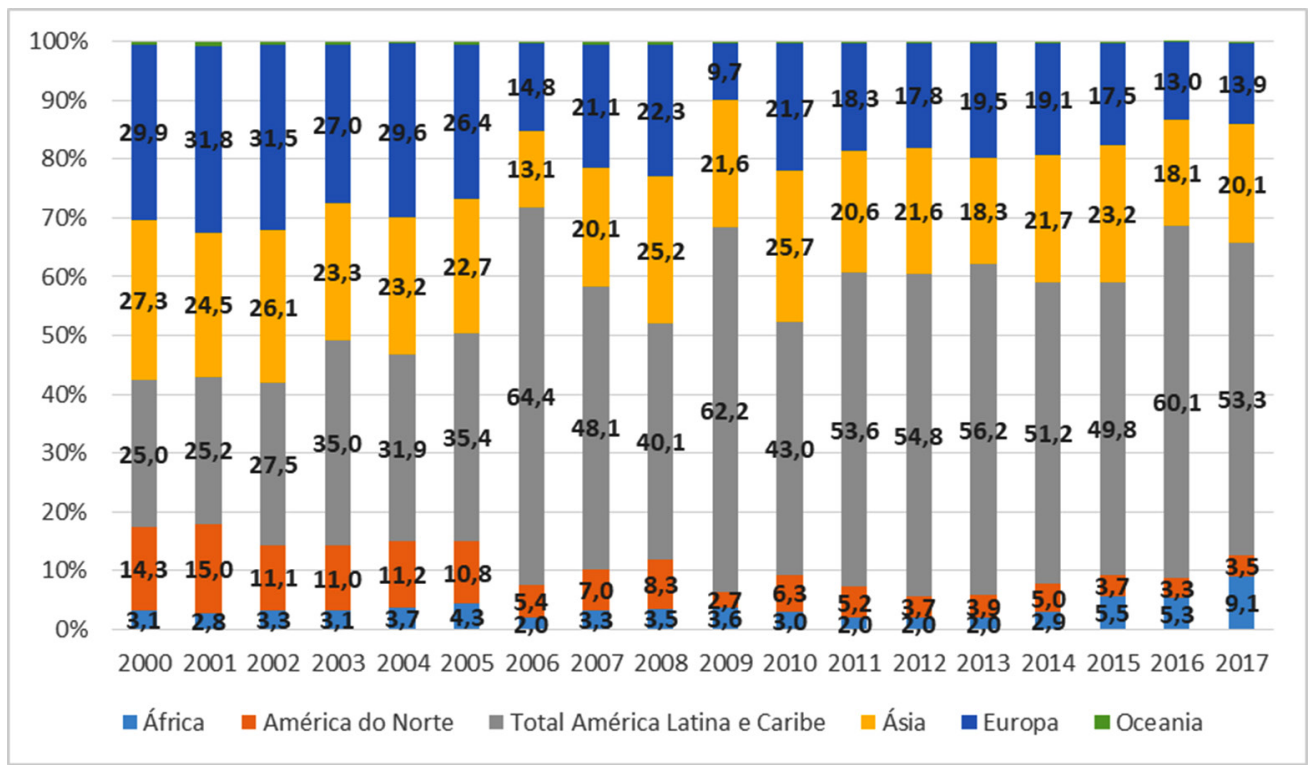

Fonte: Sistema Nacional de Cadastros e Registros (Sincre), Departamento da Polícia Federal - Ministério da Justiça e Segurança Pública do Brasil/OBMigra.

Tabulações: Observatório das Migrações em São Paulo - Nepo/Unicamp-CNPq. 


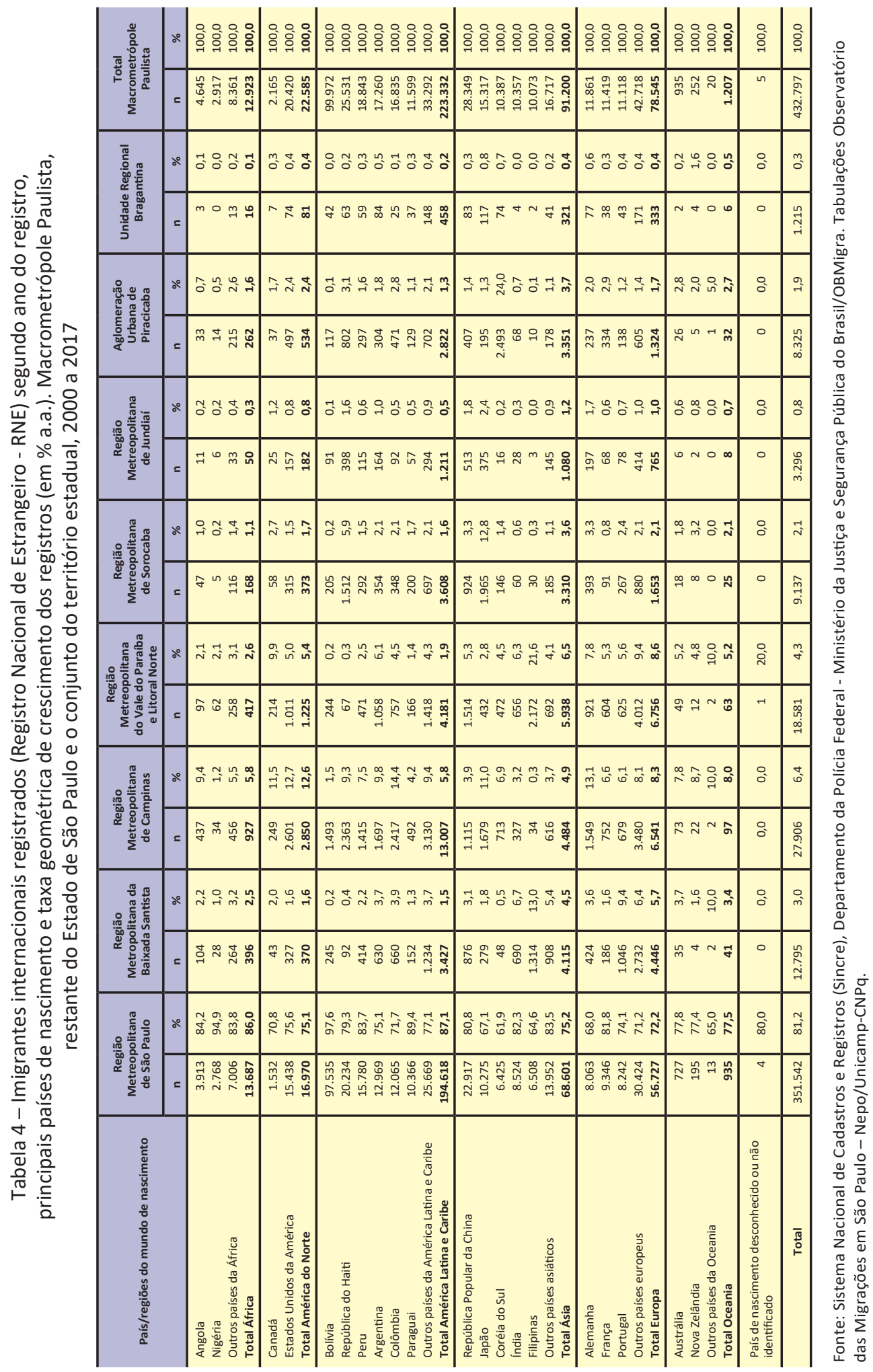


O fortalecimento dos fluxos Sul-Sul expressa tanto o reposicionamento de países e regiões do mundo na hierarquia transnacional de poder (Sassen, 1998), quando à adoção de políticas migratórias mais restritivas pelos países do Norte Global (Phelps, 2014). Nesse cenário geopolítico global, os avanços legislativos verificados no Brasil também valem nota (Assis, 2018). Mesmo diante das restrições impostas pelo Estatuo do Estrangeiro, a promulgação de resoluções normativas específicas do Conselho Nacional de Imigração (CNIg) ampliaram as possibilidades de residência documentada em território brasileiro, fortalecendo o Brasil como país de trânsito migratório no contexto internacional (Baeninger, 2017a).

Para Baeninger (2018), parte importante dessa migração Sul-Sul é composta por solicitantes de refúgio ingressos no País via fronteiras terrestres. Esse fenômeno não apenas redefine tais espacialidades (ibid.), como também articula as migrações internacionais da fronteira às migrações internacionais da metrópole (Demétrio, Domeniconi, 2018). Esses espaços, antes tratados como localidades com dinâmicas migratórias apartadas (Peres, 2018), passam a compor, cada vez mais, diferentes partes de uma rede migratória (Truzzi, 2008) de dimensões transnacionais (Glick Schiller, 2007).

Mesmo sem contemplar solicitantes de refúgio, o Sincre já aponta centralidade crescente das entradas pelas fronteiras terrestres, sobretudo da Região Norte (Mapa 3). Entre os imigrantes internacionais registrados que declararam residir na Macrometrópole Paulista, os ingressos por Roraima, Amazonas, Acre, Mato Grosso do Sul e Paraná vêm aumentando significativamente desde 2000 (Mapa 3).

Mapa 3 - Imigrantes internacionais registrados (Registro Nacional de Estrangeiro - RNE), residentes na Macrometrópole Paulista, segundo UF de ingresso no Brasil em 2000, 2010 e 2017
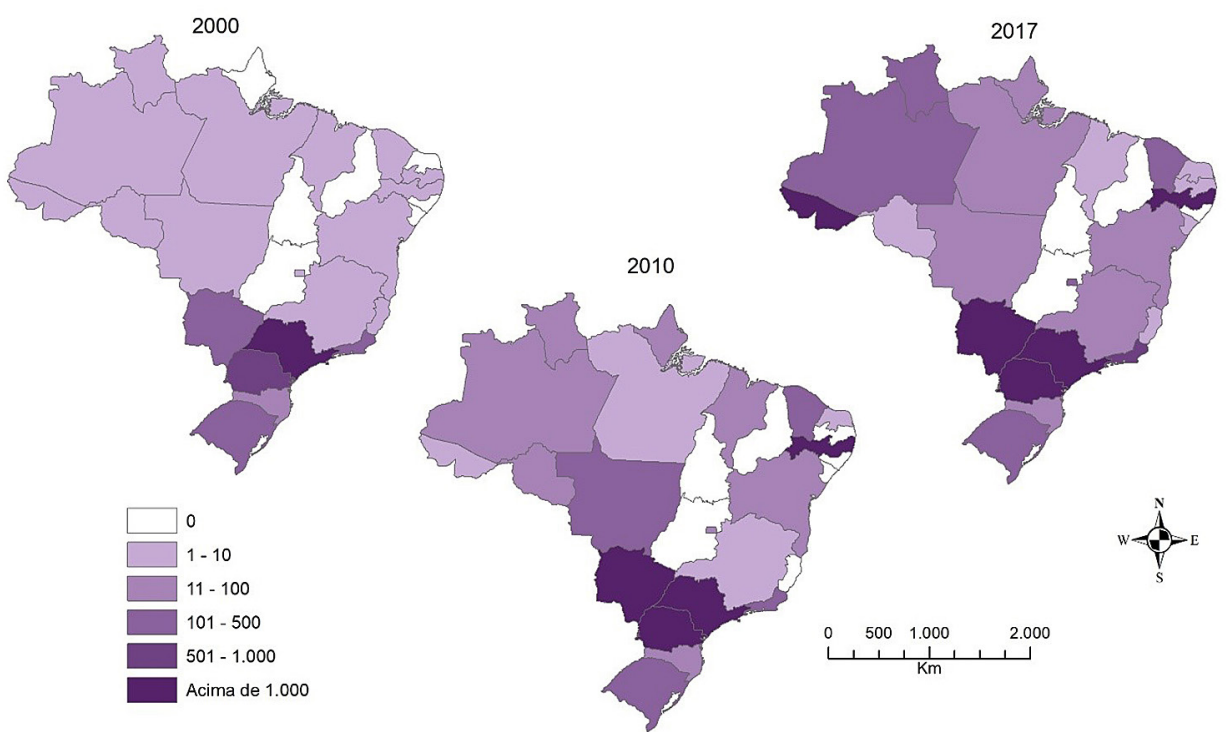

Fonte: Sistema Nacional de Cadastros e Registros (Sincre), Departamento da Polícia Federal - Ministério da Justiça e Segurança Pública do Brasil/OBMigra.

Tabulações: Observatório das Migrações em São Paulo - Nepo/Unicamp-CNPq. 
No entanto, é entre os solicitantes de refúgio que tanto as migrações Sul-Sul, como as migrações transnacionais na fronteira (Baeninger, 2018), despontam-se com maior vigor (Baeninger, 2017a). A seguir, são feitos breves apontamentos sobre as migrações transnacionais de refúgio (Baeninger, 2017b) na Macrometrópole Paulista.

\section{Imigração refugiada na Macrometrópole Paulista: tendências recentes}

Em março de 2018, o Brasil possuía 5.314 registros ativos de refugiados, dos quais 2.747 $(51,6 \%)$ declararam residir no estado de São Paulo no momento de emissão do registro. A Macrometrópole Paulista concentrava 94,7\% desses registros, o que corresponde a 2.603 pessoas vivendo sob essa condição, na data em questão. Embora ainda bastante concentrada em São Paulo, sobretudo em sua capital, a migração refugiada também dá indícios de passar por um maior espraiamento em território brasileiro, sobretudo entre os estados da Região Sul e Oeste Paulista (Baeninger; Fernandes, 2018; Mapa 4). No interior do espaço metropolitano, além da capital - que sozinha reúne 2.076 refugiados -, destacam-se também os municípios de Guarulhos, São Bernardo do Campo e Campinas (Mapa 4).

Contrapondo-se ao pequeno número de refugiados reconhecidos, a fila de processos à espera de julgamento pelo Conare contava com nada menos que 170.332 casos, em 4 de abril de 2019 (Tabela 5). Embora essa estimativa não seja publicada por município, haja vista a posição da Macrometrópole Paulista e, em especial, do município de São Paulo, na divisão nacional e internacional do trabalho, pode-se supor que parte importante dessas pessoas tenha suas trajetórias e redes conectadas às dinâmicas dessa espacialidade. Mesmo diante da importância crescente da fronteira Norte na composição desse fenômeno - concentrando quase $65 \%$ de todos os pedidos de refúgio ativos -, São Paulo permanece uma centralidade importante, com expressivos $20 \%$ das solicitações ativas (Tabela 5).

A diferença entre o total de pedidos de refúgio registrados e a quantidade de solicitações deferidas pelo Conare representa o que Baeninger (2017b) denomina crise migratória no destino. Se, na origem, estão os condicionantes "econômicos, políticos, civis, religiosos, ideológicos e humanitários", no destino, essa crise manifesta-se pelos regimes de controle, morosidade na aplicação da lei e formas de regulamentação dessa migração (ibid., p. 81). Levando-se em consideração ambos os contextos, a autora propõe um entendimento ampliado da migração refugiada que, não restrita à dimensão jurídica, contemple não apenas os refugiados reconhecidos, mas também solicitantes, concessões especiais de visto e até mesmo casos indeferidos (ibid.).

As informações apresentadas nos Mapas 5 e 6 reforçam essa migração de crise como uma dimensão fundamental das migrações Sul-Sul (Baeninger et al., 2018). Entre os refugiados reconhecidos com registro ativo, Síria, República Democrática do Congo, Palestina, Colômbia e Angola são as principais nacionalidades, concentrando, respectivamente, $41,9 \%$, $13,9 \%, 6,8 \%, 5,9 \%$ e $4,3 \%$ dos 2.747 casos registrados (Mapa 5). Já, entre os solicitantes, destacam-se Angola (3.927), Haiti (3.638), China (3.625), Síria (2.813), Nigéria (2.403), 
Mapa 4 - Refugiados com registro ativo em março de 2018, segundo UF e município de residência no Brasil e na Macrometrópole Paulista

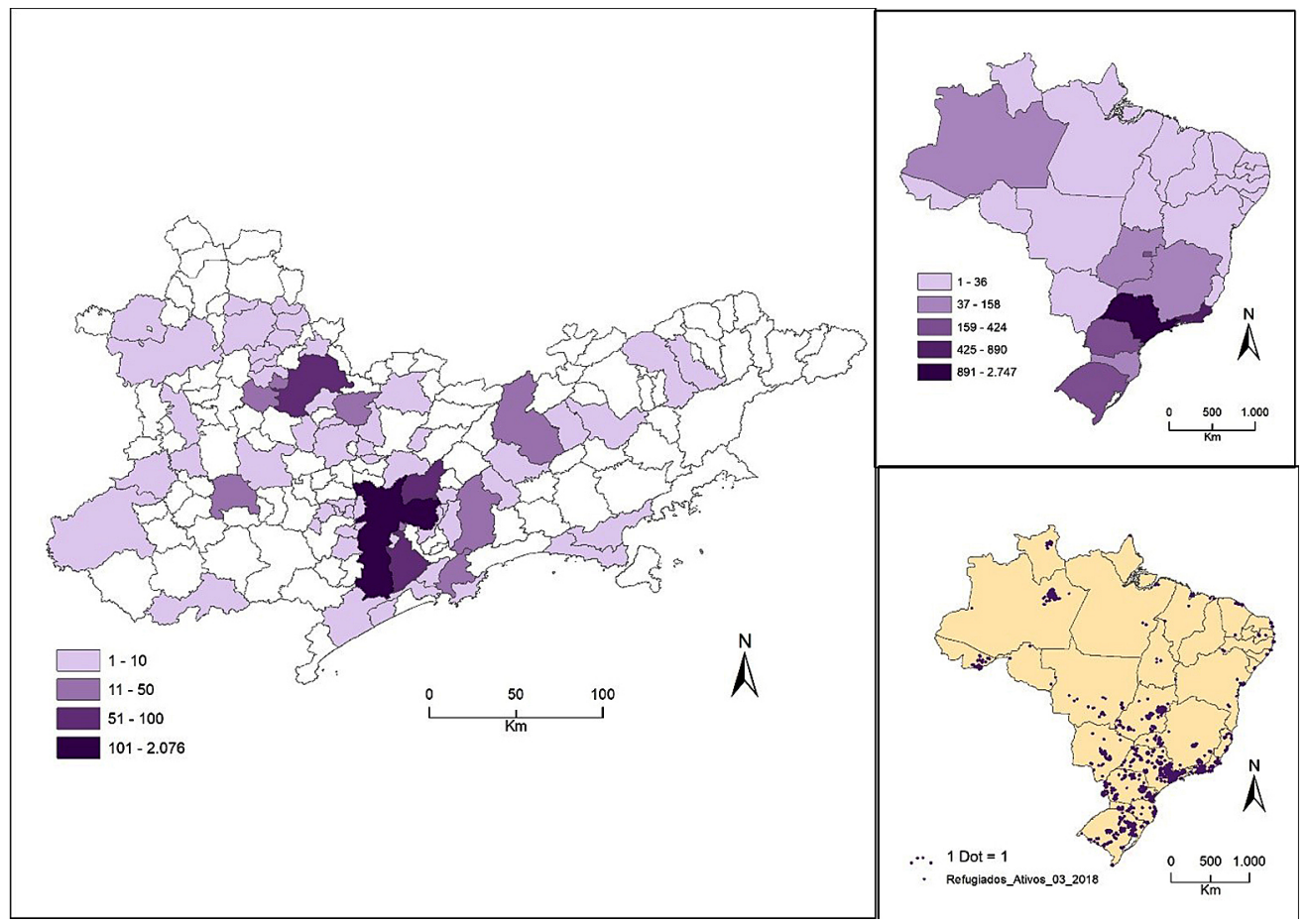

Fonte: Comitê Nacional para Refugiados (Conare), Ministério da Justiça do Brasil, 2019. Tabulações: Observatório das Migrações em São Paulo - Nepo/Unicamp-Fapesp/CNPq.

Mapa 5 - Refugiados com registro ativo em março de 2018, residentes no estado de São Paulo, segundo nacionalidade

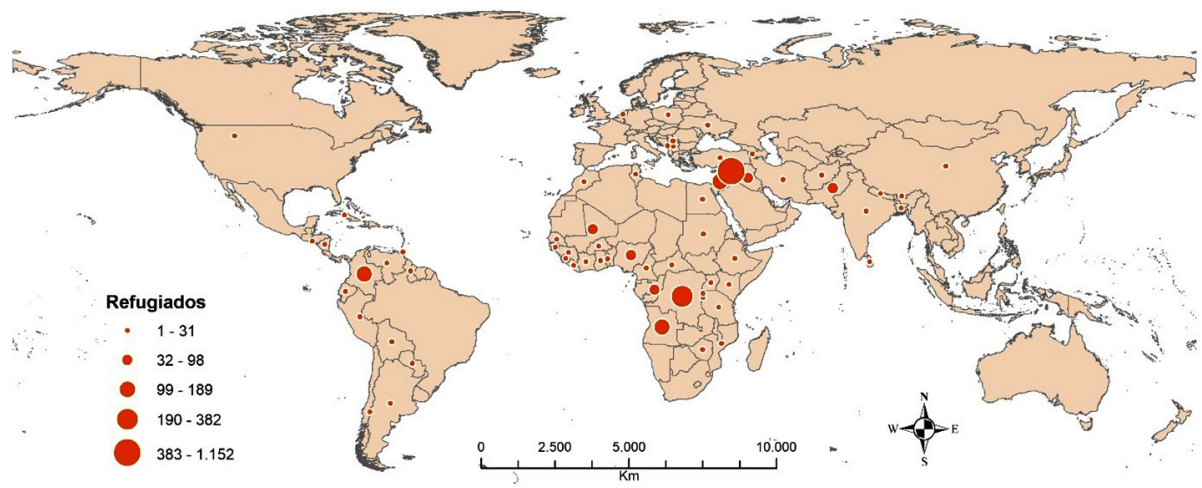

Fonte: Comitê Nacional para Refugiados (Conare), Ministério da Justiça do Brasil, 2019. Tabulações: Observatório das Migrações em São Paulo - Nepo/Unicamp-Fapesp/CNPq. 
Tabela 5 - Solicitações de refúgio ativas em 24/04/2019, segundo ano e Unidade da Federação de solicitação

\begin{tabular}{|c|c|c|c|c|c|c|c|c|c|c|c|c|}
\hline $\begin{array}{l}\text { Unidades da } \\
\text { Federação }\end{array}$ & 2002 & 2006 & 2011 & 2013 & 2014 & 2015 & 2016 & 2017 & 2018 & $\begin{array}{l}2019 \text { (até } \\
4 \text { de abril) }\end{array}$ & Total & $\%$ \\
\hline RO & 0 & 0 & 0 & 2 & 3 & 4 & 7 & 115 & 390 & 69 & 590 & 0,35 \\
\hline AC & 0 & 1 & 0 & 866 & 1.758 & 3.585 & 124 & 510 & 261 & 68 & 7.173 & 4,21 \\
\hline AN & 0 & 0 & 0 & 429 & 344 & 529 & 852 & 2.418 & 10.272 & 2.953 & 17.797 & 10,45 \\
\hline RR & 0 & 1 & 0 & 138 & 133 & 745 & 2.526 & 13.796 & 50.422 & 16.114 & 83.875 & 49,24 \\
\hline PA & 0 & 0 & 0 & 4 & 6 & 11 & 24 & 40 & 153 & 38 & 276 & 0,16 \\
\hline AP & 0 & 0 & 0 & 6 & 4 & 1 & 0 & 70 & 75 & 20 & 176 & 0,10 \\
\hline TO & 0 & 0 & 0 & 0 & 0 & 0 & 4 & 10 & 16 & 11 & 41 & 0,02 \\
\hline Região Norte & 0 & 2 & 0 & 1.445 & 2.248 & 4.875 & 3.537 & 16.959 & 61.589 & 19.273 & 109.928 & 64,54 \\
\hline MA & 0 & 0 & 0 & 0 & 1 & 0 & 2 & 21 & 51 & 36 & 111 & 0,07 \\
\hline PI & 0 & 0 & 0 & 0 & 0 & 1 & 0 & 0 & 13 & 0 & 14 & 0,01 \\
\hline CE & 0 & 0 & 1 & 7 & 20 & 86 & 84 & 125 & 490 & 79 & 892 & 0,52 \\
\hline $\mathrm{RN}$ & 0 & 0 & 0 & 11 & 3 & 1 & 5 & 20 & 22 & 23 & 85 & 0,05 \\
\hline PB & 0 & 0 & 0 & 0 & 0 & 0 & 0 & 7 & 23 & 24 & 54 & 0,03 \\
\hline PE & 0 & 0 & 0 & 8 & 0 & 3 & 27 & 47 & 65 & 31 & 181 & 0,11 \\
\hline AL & 0 & 0 & 0 & 0 & 0 & 0 & 0 & 9 & 30 & 2 & 41 & 0,02 \\
\hline SE & 0 & 0 & 0 & 0 & 0 & 0 & 0 & 8 & 49 & 7 & 34 & 0,02 \\
\hline BA & 0 & 0 & 0 & 4 & 3 & 1 & 19 & 50 & 105 & 47 & 229 & 0,13 \\
\hline Região Nordeste & 0 & 0 & 1 & 30 & 27 & 92 & 137 & 287 & 818 & 249 & 1.641 & 0,96 \\
\hline MG & 0 & 0 & 0 & 26 & 39 & 16 & 12 & 165 & 296 & 322 & 876 & 0,51 \\
\hline ES & 0 & 0 & 0 & 19 & 87 & 27 & 5 & 21 & 42 & 23 & 224 & 0,13 \\
\hline RJ & 0 & 0 & 0 & 277 & 228 & 611 & 488 & 565 & 701 & 380 & 3.250 & 1,91 \\
\hline SP & 1 & 0 & 0 & 1.389 & 4.115 & 6.348 & 2.487 & 7.854 & 9.412 & 3.397 & 35.003 & 20,55 \\
\hline Região Sudeste & 1 & 0 & 0 & 1.711 & 4.469 & 7.002 & 2.992 & 8.605 & 10.451 & 4.122 & 39.353 & 23,10 \\
\hline PR & 0 & 0 & 0 & 845 & 850 & 720 & 229 & 592 & 1.302 & 490 & 5.028 & 2,95 \\
\hline SC & 0 & 0 & 0 & 304 & 521 & 456 & 198 & 769 & 1.712 & 851 & 4.811 & 2,82 \\
\hline RS & 0 & 0 & 0 & 453 & 865 & 581 & 205 & 600 & 1.113 & 322 & 4.139 & 2,43 \\
\hline Região Sul & 0 & 0 & 0 & 1.602 & 2.236 & 1.757 & 632 & 1.961 & 4.127 & 1.663 & 13.978 & 8,21 \\
\hline MS & 0 & 0 & 0 & 47 & 35 & 42 & 46 & 76 & 170 & 113 & 529 & 0,31 \\
\hline MT & 0 & 0 & 0 & 7 & 5 & 41 & 33 & 135 & 641 & 158 & 1.020 & 0,60 \\
\hline GO & 0 & 0 & 0 & 315 & 50 & 9 & 20 & 82 & 165 & 147 & 788 & 0,46 \\
\hline DF & 0 & 0 & 0 & 1.076 & 731 & 420 & 243 & 255 & 254 & 116 & 3.095 & 1,82 \\
\hline Região Centro-Oeste & 0 & 0 & 0 & 1.445 & 821 & 512 & 342 & 548 & 1.230 & 534 & 5.432 & 3,19 \\
\hline Brasil & 1 & 2 & 1 & 6.233 & 9.801 & 14.238 & 7.640 & 28.360 & 78.215 & 25.841 & 170.332 & 100,00 \\
\hline
\end{tabular}

Fonte: Comitê Nacional para Refugiados (Conare), Ministério da Justiça do Brasil, 2019. Tabulações Observatório das Migrações em São Paulo - Nepo/Unicamp-Fapesp/CNPq.

Bangladesh (2.018), Venezuela (1.405), Cuba (1.343) e República do Congo (1.181), os quais, juntos, respondem por quase $64 \%$ de todas as 35.003 solicitações ativas (Mapa 6).

Nesse contexto, Baeninger (2017a) analisa a consolidação do Brasil na rota das migrações transnacionais como país de trânsito, desde a vertente dos periféricos na periferia
(Baeninger, 2017 apud Basso, 2003). Nessa nova fase da imigração internacional para 0 País, o protagonismo das migrações Sul-Sul traz processos migratórios completamente novos, ao mesmo tempo que fenômenos com raízes históricas são imbuídos de um novo significado, a exemplo da migração refugiada (Baeninger, 2017a). 
Mapa 6 - Solicitantes de refúgio com registro ativo em 4/4/2019, que fizeram a solicitação no estado de São Paulo, segundo nacionalidade

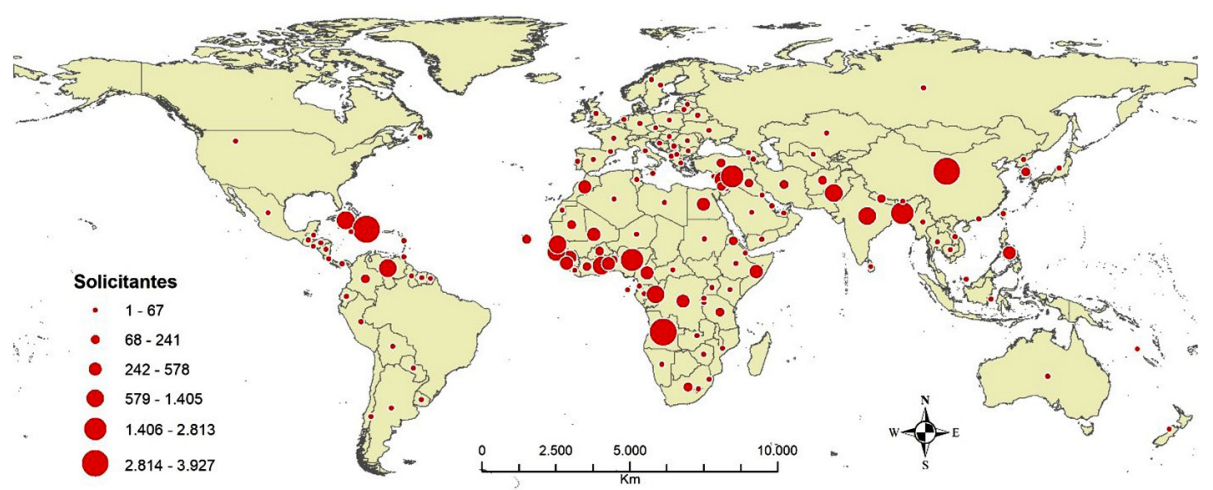

Fonte: Comitê Nacional para Refugiados (Conare), Ministério da Justiça do Brasil, 2019.

Tabulações: Observatório das Migrações em São Paulo - Nepo/Unicamp-Fapesp/CNPq.

\section{Considerações finais}

As mudanças no âmbito da divisão internacional do trabalho (Sassen, 1998), a emergência dos processos de reestruturação da produção (Harvey, 1992), a reconversão econômica assistida pela principal metrópole do País (Magalhães; Bógus, 2018), desencadeiam, não apenas a expansão da área de influência direta da cidade de São Paulo, borrando divisões político-administrativas tradicionais (Lencioni, 2003; Moura, 2009), como também alteram a dinâmica de reprodução de sua força de trabaIho (Faria, 1981), com participação crescente de imigrantes internacionais (Baeninger, 2014). Desde essa perspectiva, as reflexões e resultados deste artigo são relevantes na medida em que buscam vincular o fenômeno da imigração internacional à formação de arranjos espaciais (Moura, 2009) que se articulam para além da capital, "envolvendo municípios de estrutura econômica e social bastante distinta" (MagaIhães et al., 2018, p.19). Nesse sentido, a nova imigração internacional (Baeninger, 2017a) para a Macrometrópole Paulista (Emplasa, 2011 e 2012) soma-se aos fluxos passados, redefinindo "a forma com que esses grupos se relacionam com o espaço urbano" e fazendo dessa região um terreno "fértil para o estudo das migrações e do refúgio internacional" (Magalhães; Bógus; Baeninger, 2018, p. 405).

Assim, a migração internacional na principal aglomeração metropolitana do País está perpassada de novas e velhas questões. Por um lado, a existência de uma estrutura consolidada de acolhimento e acompanhamento a imigrantes e refugiados faz do município de São Paulo uma localidade referência na trajetória de diferentes grupos imigrantes (Magalhães e Bógus, 2018). Por outro lado, os processos 
de reestruturação urbana e produtiva empurram parte importante dos migrantes de baixa qualificação para regiões cada vez mais distantes do núcleo metropolitano (Magalhães; Bógus; Baeninger, 2018). Ao mesmo tempo, o fenômeno da reconversão econômica e a consequente ampliação das funções de direção e inovação tecnológica, somada à presença de um dos parques produtivos mais integrados do Brasil (Campolina Diniz; Campolina, 2007), associam-se à presença da migração internacional altamente qualificada, fazendo desse arranjo urbano metropolitano (Moura, 2009) uma constelação de diferentes espaços da migração (Baeninger, 2012), os quais denotam as dinâmicas multiescalares de sua inserção na divisão socioespacial do trabalho em nível local/ regional, nacional e global.

\section{[1] http://orcid.org/0000-0002-3817-2807}

Universidade Estadual de Campinas, Instituto de Filosofia e Ciências Humanas, Departamento de Sociologia e Demografia, Núcleo de Estudos de População "Elza Berquó". Campinas, SP/Brasil. baeninger@nepo.unicamp.br

\section{[II] http://orcid.org/0000-0003-0954-6993}

Universidade Estadual de Campinas, Instituto de Filosofia e Ciências Humanas, Programa de Pós-Graduação em Demografia, Núcleo de Estudos de População "Elza Berquó". Campinas, SP/Brasil. natalia_belmontedemetrio@yahoo.com.br

\section{[III] http://orcid.org/0000-0002-5606-448X}

Universidade Estadual de Campinas, Instituto de Filosofia e Ciências Humanas, Programa de Pós-Graduação em Demografia. Campinas, SP/Brasil. joicedomeniconi@nepo.unicamp.br

\section{Notas}

(1) É importante destacar o crescente acesso à documentação na dinamização dos fluxos migratórios internacionais recentes para o Brasil (Fernandes et al., 2014). Seja em função de acordos multilaterais (tais como os firmados entre os países do Mercado Comum do Sul), das concessões especiais de visto (como o visto de ajuda humanitária conferido aos haitianos) ou das garantias previstas a todos os solicitantes de refúgio, Fernandes et al. (2014) pontuam a diminuição considerável de imigrantes internacionais em situação de indocumentação.

(2) Os dois registros administrativos descritos possibilitam desagregação da informação no nível de município e apresentam periodicidade anual. Por isso são amplamente utilizados em pesquisas acadêmicas e diagnósticos (Baeninger e Fernandes, 2017; Oliveira e Cavalcante, 2015). 
(3) Os microdados do Sincre estão disponíveis em: http://obmigra.mte.gov.br/index.php/microdados. Acesso em: 30 mar 2019.

(4) As informações do Sincre passaram a ser de consulta pública apenas em 2017.

(5) Levando em consideração que decoradores são, sobretudo, bolivianos, essa ocupação deve estar associada ao nicho da costura (Baeninger; Fernandes, 2017). Outra ocupação que precisa ser considerada com precaução é a de arquitetos.

\section{Referências}

ASSIS, G. de O. (2018). "Nova Lei de Migração no Brasil: Avanços e Desafios”. In: BAENINGER, R. et al. Migrações Sul-Sul. Campinas, SP, Nepo/Unicamp.

BAENINGER, R. (2005). São Paulo e suas migrações no final do século XX. São Paulo em Perspectiva, v. 19, n. 3, pp. 84-96.

(2012). Fases e faces da migração em São Paulo. Campinas, Núcleo de Estudos de População - Nepo/Unicamp.

(2014). Migrações Internacionais no século 21: desafios para uma agenda de pesquisa. In: VI CONGRESO DE LA ASOCIACIÓN LATINOAMERICANA DE POBLACIÓN. Anais... Lima-Peru, de 12 a 15 de agosto.

(2017a). “Cenários das Migrações Internacionais no Brasil”. In: BERQUÓ, E. (org.). Demografia na Unicamp: um olhar sobre a produção do Nepo. Campinas-SP, Editora da Unicamp.

(2017b). "Migrações transnacionais de refúgio no Brasil”. In: LUSSI, C. (org.). Migrações Internacionais: Abordagens de Direitos Humanos. Brasília, Centro Scalabriniano de Estudos Migratórios, v. 1, pp. 13-29.

BAENINGER, R. et al. (orgs.) (2018). Migrações Sul-Sul. Campinas, SP, Nepo/Unicamp.

BAENINGER, R. e CANALES, A. (coords.) (2018). Migrações fronteiriças. Campinas, SP, Nepo/Unicamp.

BAENINGER, R. e CUSTÓDIO, F. (coords.) (2018). Atendimento ao Imigrante da Prefeitura Municipal de Campinas-SP: perfil de imigrantes internacionais registrados no Serviço de Referência ao Imigrante, Refugiado e Apátrida.. Disponível em: http://www.nepo.unicamp.br/catedra/ Diagn\%C3\%B3stico\%20do\%20Munic\%C3\%ADpio\%20de\%20Campinas_C\%C3\%A1tedra.pdf. Acesso em: 25 maio 2018.

BAENINGER, R. e FERNANDES, D. (coords.) (2017). Atlas temático: observatório das migrações em São Paulo - Migrações internacionais. Campinas, SP, Nepo/Unicamp.

(coords.) (2018). Atlas temático: observatório das migrações em São Paulo - Migração refugiada. Campinas, SP, Nepo/Unicamp,.

BASSO, R. (2013). "Imigração, racismo e antirracismo na Europa hoje”. In: TAVARES, M. A.; GOMES, C. (orgs.). Intermitências da crise e questão social: uma interpretação marxista. João Pessoa, Editora UFPB. 
BRANDÃO, C. A. (2007). Território e desenvolvimento: as múltiplas escalas entre o local e o global. Campinas, Editora da Unicamp.

CAMPOLINA DINIZ, C. e CAMPOLINA, B. (2007). A região metropolitana de São Paulo: reestruturação, re-espacialização e novas funções. Eure. Santiago, v. 33, n. 98, pp. 27-43.

CANO, W. (2011). Novas determinações sobre as questões regional e urbana após 1980. Texto para discussão. Campinas, IE/Unicamp, n. 193, pp. 1-36, julho.

DEMÉTRIO, N. B. (2017). Arranjos urbanos-rurais regionais: o rural paulista no século 21. Tese de Doutorado. Campinas, Universidade Estadual de Campinas.

DEMÉTRIO, N. B. e DOMENICONI, J. (2018). "Imigração venezuelana no Brasil: o espaço da fronteira e o espaço da metrópole”. In: BAENINGER, R. e SILVA, J. C. J. (orgs.). Migrações venezuelanas. Campinas, SP, Nepo/Unicamp.

DOMENICONI, J. (2018). "A migração internacional qualificada no século XXI - A circulação de trabalhadores do conhecimento desde uma perspectiva Sul-Sul”. In: BAENINGER, R.; BÓGUS, L. M.; MOREIRA, J. B.; VEDOVATO, L. R.; FERNANDES, D.; SOUZA, M. R. de; BALTAR, C. S.; PERES, R. G.; WALDMAN, T. C. e MAGALHÃES, L. F. (orgs.). Migrações Sul-Sul. Campinas, SP, Nepo/Unicamp.

ELIAS, D. (2003). Globalização e agricultura. São Paulo, Edusp.

(2017). Agronegócio globalizado e (re)estruturação urbano-regional. In: XVII ENCONTRO NACIONAL DA ASSOCIAÇÃO NACIONAL DE PÓS-GRADUAÇÃO E PESQUISA EM PLANEJAMENTO URBANO E REGIONAL. Anais... São Paulo, 22 a 26 de maio.

EMPLASA/SEADE (2011). Rede Urbana e Regionalização do Estado de São Paulo. São Paulo, Emplasa. Disponível em: http://produtos.seade.gov.br/produtos/publicacoes/pub_ RedeUrbanaRegionalizacaoESP_2011.pdf. Acesso em: 20 fev 2019.

EMPLASA - Empresa Paulista de Planejamento Metropolitano (2012). Macrometrópole Paulista, 2012. São Paulo, Secretaria de Desenvolvimento Metropolitano - Emplasa. Disponível em: https://cetesb.sp.gov.br/camaras-ambientais/wp-content/uploads/sites/21/2014/12/ Macrometropole.pdf. Acesso em: out 2018.

FARIA, V. (1981). Divisão social do trabalho, especialização e crescimento urbano: o caso da macrometrópole paulista. In: II ENCONTRO NACIONAL DA ASSOCIAÇÃO BRASILEIRA DE ESTUDOS POPULACIONAIS. Anais. S.I., Abep.

FERNANDES, D. et al. (2014). Estudos sobre a Imigração no Brasil e Diálogo Bilateral. Relatório Ministério do Trabalho/OIM/PUCMinas.

GLICK-SCHILLER, N. (2007). Beyond the Nation-State and Its Units of Analysis: Towards a New Research Agenda for Migration Studies - Essentials of Migration Theory. In: CENTER ON MIGRATION, CITIZENSHIP AND DEVELOPMENT. Arbeitspapiere - Working Papers, n. 33.

HARVEY, D. (1992). A condição pós-moderna. São Paulo, Loyola.

LENCIONI, S. (2003). A emergência de um novo fato urbano de caráter metropolitano em São Paulo: a particularidade de seu conteúdo socioespacial, seus limites regionais e sua interpretação teórica. In: X ENCONTRO NACIONAL DA ANPUR. Anais... Belo Horizonte.

MAGALHÃES, L. F. A.; BÓGUS, L. (2018). Reconversão econômica e migrações Sul - Sul na cidade de São Paulo: fluxos e territorialidades migrantes. In: XXI ENCONTRO NACIONAL DA ASSOCIAÇÃO BRASILEIRA DE ESTUDOS POPULACIONAIS. Anais... Poços de Caldas, Abep. 
MAGALHÃES, L. F. A.; BAENINGER, R.; DEMÉTRIO, N. B.; DOMENICONI, J. (2018). A imigração internacional contemporânea nos municípios da Macrometrópole Paulista. Trabalho apresentado no Congresso Observatório das Metrópoles vinte anos: As Metrópoles e o Direito à Cidade: dilemas, desafios e esperanças. Rio de Janeiro.

MAGALHÃES, L. F. A. (2017). A imigração haitiana em Santa Catarina: perfil sociodemográfico do fluxo, contradições da inserção laboral e dependência de remessas no Haiti. Tese de Doutorado. Campinas, Universidade Estadual de Campinas.

MAGALHÃES, L. F. A.; BÓGUS, L. M. M.; BAENINGER, R. (2018). “Migrantes e refugiados Sul-Sul na cidade de São Paulo: trabalho e espacialidades". In: BAENINGER, R.; BÓGUS, L. M.; MOREIRA, J. B.; VEDOVATO, L. R.; FERNANDES, D.; SOUZA, M. R. de; BALTAR, C. S.; PERES, R. G.; WALDMAN, T. C.; MAGALHÃES, L. F. (orgs.) Migrações Sul-Sul. Campinas, SP, Nepo/Unicamp.

MANRIQUE, L. E. (2012). El emergente eje 'Sur-Sur' gloabal. Política Exterior, marzo/abril.

MOURA, R. (2009). Arranjos urbano-regionais no Brasil: uma análise com foco em Curitiba. Tese de Doutorado. Curitiba, Universidade Federal do Paraná.

NEGRI, B.; GONÇALVES, M. F. e CANO, W. (1988). “O processo de interiorização do desenvolvimento e da urbanização no Estado de São Paulo (1920-1980)". In: CANO, W. (org.). A interiorização do desenvolvimento econômico no Estado de São Paulo (1920-1980). São Paulo, Seade.

OLIVEIRA, G. C. de (2017). Imigração boliviana no interior de São Paulo: o setor têxtil em Americana $S P$. Tese de Doutorado. Campinas, Universidade Estadual de Campinas.

OLIVEIRA, A. T.; CAVALCANTI, L. (2015). Potencialidades e limitações no uso dos registros administrativos: a experiência do OBMigra. Disponível em: <http://obmigra.mte.gov.br/index. php/component/content/article?id=1215>. Acesso em: 1o out 2017.

PERES, R. (2018). “A presença boliviana em Corumbá - MS: a construção de um espaço migratório de fronteira". In: BAENINGER, R. e CANALES, A. (coords.). Migrações fronteiriças. Campinas, SP, Núcleo de Estudos de População "Elza Berquó".

PHELPS, E. D. (2014). South-South Migration: Why it's bigger than we think, and why we should care. The Migrationist. Disponível em: themigrationist.net/2014/02/06/south-south-migration-whyits-bigger-than-we-think-and-why-we-should-care. Acesso em: 20 maio 2018.

PORTES, A.; GUARNIZO, L.; LANDOLT, P. (2003). La Globalización desde abajo: transnacionalismo inmigrante y desarrollo. México, Flasco.

SANTOS, M. (2013). Técnica, espaço, tempo. São Paulo, Editora da Universidade de São Paulo.

SASSEN, S. (1998). As cidades na economia mundial. São Paulo, Studio Nobel

TRUZZI, O. M. S. (2008). Redes em processos migratórios. Tempo Social, v. 20, pp. 199-218.

Texto recebido em 16/jun/2019

Texto aprovado em 22/ago/2019 